\title{
Occurrence of arsenic in ultramafic rocks' alterites from nickel mines in New Caledonia: implications for the contamination of surface waters
}

\author{
Kévin Schneider $^{1} \cdot$ Monika Le Mestre $^{1} \cdot$ Isabelle Desriaux $^{1} \cdot$ Peggy Gunkel-Grillon ${ }^{1}$
}

Received: 20 March 2020 / Accepted: 10 April 2020 / Published online: 21 April 2020

(c) Springer Nature Switzerland AG 2020

\begin{abstract}
Arsenate $\mathrm{As}(\mathrm{V})$ and arsenite $\mathrm{As}(\mathrm{III})$ are toxic forms of arsenic in waters. The risk of As toxicity is high in small tropical islands because tap water is often provided from surface water, and As contamination of surface water is rarely studied. For instance, the risk is high in New Caledonia because $61 \%$ of the water comes from surface water, and nickel mines induce the dispersal of large quantities of ultramafic rocks's alterites rich in iron oxide-hydroxide, which are known to be associated with arsenite and arsenate. Levels exceeding the World Health Organization standard of $10 \mu \mathrm{g} \mathrm{L}^{-1}$ have been detected in rivers downstream of Ni mines, yet there is a lack of systematic assessment. Here, we analyzed total and exchangeable As in alterites collected near three active mines. Arsenate and arsenite adsorption capacity was studied using batch experiments. The results show that alterite contains total As contents ranging from 0.20 to $5.14 \mathrm{mg} \mathrm{kg}^{-1}$, yet the primary mineralogical source of As remains unknown. No exchangeable arsenite was detected. Exchangeable arsenate amounted to $0.16 \mathrm{mg} \mathrm{kg}^{-1}$, thus meaning that $10.3 \%$ of the total As is easily mobile. The maximum adsorption capacity of arsenate and arsenite in mining sediments was $1.05 \mathrm{mg} \mathrm{kg}^{-1}$. Overall, our findings reveal that ultramafic rock alterites are a source of arsenic in surface water in the form of suspended particulate matter, $10.3 \%$ of which being easily soluble.
\end{abstract}

Keywords Ultramafic rocks' alterites · Inorganic arsenic $\cdot$ Exchangeable arsenate $\cdot$ Arsenite and arsenate adsorption capacity $\cdot$ Ultramafic watershed $\cdot$ Surface water

\section{Introduction}

Arsenic (As) is a well-known toxic metalloid and naturally found in the environment. Exposure to As may occur through contaminated drinking water, and it can increase the risk of diseases or lead to death (Sattar et al. 2016; States et al. 2009; Zhang et al. 2018). Inorganic As is found in water as $\mathrm{As}(\mathrm{V})\left(\right.$ arsenate $\mathrm{H}_{3} \mathrm{AsO}_{4}$ ) in aerobic waters (Prohaska and Stingeder 2005) and $\mathrm{As}(\mathrm{III})\left(\operatorname{arsenite} \mathrm{H}_{3} \mathrm{AsO}_{3}\right)$ in anaerobic waters (Pettine et al. 1992). As(III), more mobile, is more toxic than $\mathrm{As}(\mathrm{V})$ (Basu et al. 2014).

Electronic supplementary material The online version of this article (https://doi.org/10.1007/s10311-020-01009-6) contains supplementary material, which is available to authorized users.

Peggy Gunkel-Grillon

peggy.gunkel-grillon@unc.nc

1 Institute of Exact and Applied Sciences, University of New Caledonia, BP R4, 98851 Nouméa Cedex, New Caledonia
The occurrence of As in groundwater was studied (Smedley and Kinniburgh 2002; Bossy et al. 2012; Merola et al. 2015), but in small tropical islands, water resource often comes from surface water collection; and the arsenic risk, widely studied in groundwater, is poorly studied in surface water. In New Caledonia, $61 \%$ of the water comes from surface water and a third of the main island is covered by weathered ultramafic rocks, containing high concentrations of iron $(\mathrm{Fe})$, manganese, nickel (Ni), cobalt and chromium. The main economic activity is then Ni ore mining with 30 opencast mines. Rains can be intense under the subtropical climate and water runoff can generate ultramafic rock's alterites transport to surface waters and metals enrichment (Gunkel-Grillon et al. 2014). Water quality investigations revealed that in ultramafic catchments, the median total As in rivers may range 4-8 $\mu \mathrm{g} \mathrm{L}^{-1}$ (third quartile ranging 9.5-12 $\mu \mathrm{g} \mathrm{L}^{-1}$ ) and in a river affected by a past mining activity, it can be significantly higher with $21 \mu \mathrm{g} \mathrm{L}^{-1}$ (Juillot 2019). As content in rivers flowing in ultramafic catchments can then exceed the World Health Organization recommended $10 \mu \mathrm{g} \mathrm{L}^{-1}$ value 
and an exacerbated solid transport seems to increase As content in rivers. Alterites are rich in iron oxides and hydroxides and goethite $(\alpha-\mathrm{FeOOH})$ is the main mineral phase (Becquer et al. 2001). Iron oxides-hydroxides have been recognized as a solid phase source of As, but as pointed out by Seddique et al. (2008), they are secondary phases that form during weathering or diagenetic alteration, and in many cases, the primary mineralogical source of As is unknown. Many studies also illustrated the high affinity of As(III) and As(V) for pure, natural or modified iron oxides and hydroxides in order to determine their efficiency to clean water with very high adsorption capacities ranging $0.6-442.8 \mathrm{mg} \mathrm{g}^{-1}$ (Siddiqui and Chaudhry 2017; Nguyen and Tran 2020). Moreover, As in groundwater can be derived from ultramafic rocks dissolution (Ryan et al. 2011). These data suggest that massive ultramafic rocks alterites dispersal due, among others, to mining activities should be a source of As to surface waters in laterized ultramafic watershed and pose problems for the surface water quality in New Caledonia and more broadly in small tropical islands.

To test the hypothesis that ultramafic rocks alterites can be a significant As source in surface waters, their total arsenic content around $\mathrm{Ni}$-mining sites was analyzed, and their ability to release or adsorb As was also investigated. To the best of our knowledge, this is the first investigation on arsenic risk associated with potential ultramafic rock's alterites dispersal in ultramafic catchments.

\section{Experimental}

\section{Sites description}

The climate of New Caledonia is subtropical with $1700 \mathrm{~mm}$ annual rainfall and the mean annual temperature is $25^{\circ} \mathrm{C} .33$ samples were collected from the top layer $0-10 \mathrm{~cm}$ in three different mining areas, the Mont Koniambo, Poro and Maï Kouaoua Mines (Fig. 1). K1 to K10 and P1 to P10 are mining technosoils. K-C3-A, K-C3-B, K-T, M-3B, M-3C, P-E, $\mathrm{P}-\mathrm{G}$ and $\mathrm{P}-\mathrm{H}$ are mining sediments sampled in decanters or on banks of impacted rivers. K-C1, K-C2, K-FA1, M-2 and $\mathrm{M}-3 \mathrm{~A}$ are river sands and $\mathrm{P}-\mathrm{F}$ is beach sand, collected downstream mining sites.

\section{Physicochemical parameters of alterites}

Samples were dried at $45{ }^{\circ} \mathrm{C}$. The $\mathrm{pH}$ and redox potential were measured in ultrapure water (1/5 mass/volume). $\mathrm{pH}$

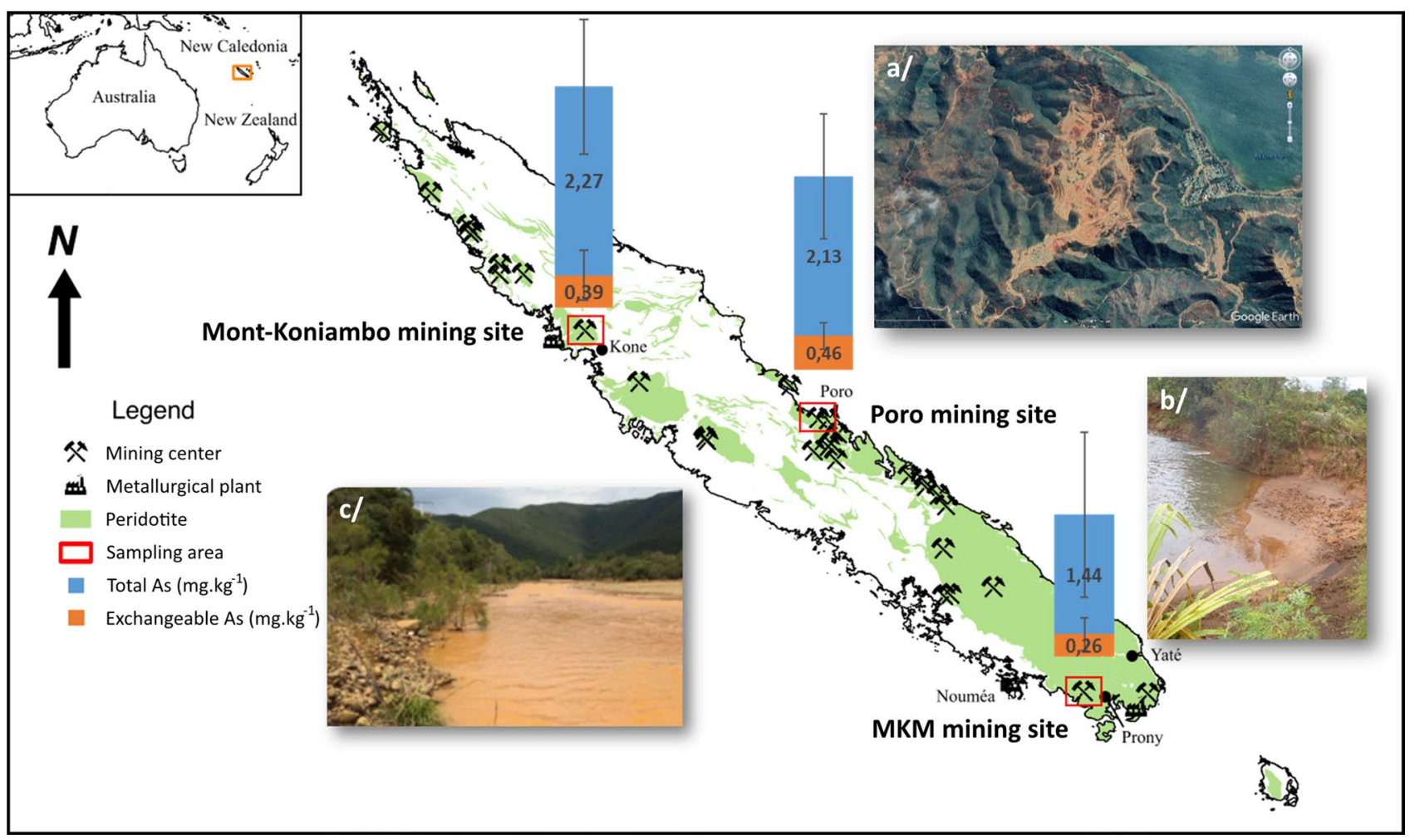

Fig. 1 Sampling mining site in the North (Mont Koniambo), East (Poro) and South (MKM) in New Caledonia a/opencast mine in Poro, $\mathrm{b} /$ mining sediments on the banks of a river downstream off the MKM mine and c/mining sediments dispersal in Talea-Coco river down- stream Mont Koniambo mine. As was detected in the three mining sites and with no difference in total mean content or in exchangeable mean As contents in ultramafic rocks' alterites 
values are approximately neutral and redox potential ranges 126-274 mV (Table 1). According to potential/pH diagram, As is expected to be As(V).

The particle-size distribution was determined with a Mastersizer S2000 laser particle-size analyzer (Malvern, UK), particle and water refractive indices of 2.9 and 1.33. The median diameter $\left(D_{0.5}\right.$ in $\left.\mu \mathrm{m}\right)$ is the central tendency of the size distribution.

Mineralogical characterization was determined by X-ray diffraction (INEL CPS $120^{\circ}$ curved
Table 1 Physicochemical properties of ultramafic rocks' alterites and their total and exchangeable As content

\begin{tabular}{|c|c|c|c|c|c|c|c|c|}
\hline \multirow[t]{2}{*}{ Site } & \multirow[t]{2}{*}{ Samples } & \multirow[t]{2}{*}{$\mathrm{pH}$} & \multirow{2}{*}{$\begin{array}{l}E_{\mathrm{h}} \\
(\mathrm{mV})\end{array}$} & \multirow{2}{*}{$\begin{array}{l}D_{0.5} \\
(\mu \mathrm{m})\end{array}$} & \multirow{2}{*}{$\begin{array}{l}\text { Main mineral } \\
\text { phases }\end{array}$} & \multirow{2}{*}{$\begin{array}{l}\text { Total As } \\
\left(\mathrm{mg} \mathrm{kg}^{-1}\right)\end{array}$} & \multicolumn{2}{|c|}{ Exchangeable As(V) } \\
\hline & & & & & & & $\left(\mathrm{mg} \mathrm{kg}^{-1}\right)$ & $(\%)$ \\
\hline \multirow[t]{18}{*}{ Mont Koniambo } & \multicolumn{8}{|c|}{ Mining technosoil } \\
\hline & $\mathrm{K} 1$ & 5.6 & 274 & 32 & $\mathrm{G}, \mathrm{H}, \mathrm{Q}, \mathrm{A}$ & $2.72 \pm 0.36$ & $0.29 \pm 0.04$ & $10.6 \pm 1.5$ \\
\hline & $\mathrm{K} 2$ & 6.9 & 169 & 35 & $\mathrm{G}, \mathrm{H}$ & $5.14 \pm 0.60$ & n.a & - \\
\hline & K3 & 7.4 & 141 & 39 & $\mathrm{G}, \mathrm{H}, \mathrm{Q}, \mathrm{L}$ & $1.06 \pm 0.09$ & $0.11 \pm 0.02$ & $10.0 \pm 2.3$ \\
\hline & K4 & 7.1 & 155 & 47 & $\mathrm{G}, \mathrm{H}, \mathrm{Q}, \mathrm{L}$ & $0.42 \pm 0.08$ & $0.14 \pm 0.04$ & $33.8 \pm 9.5$ \\
\hline & K5 & 6.9 & 140 & 16 & $\mathrm{G}, \mathrm{Q}, \mathrm{T}, \mathrm{L}$ & $0.20 \pm 0.02$ & $0.16 \pm 0.03$ & $78.5 \pm 14$ \\
\hline & K6 & 6.5 & 164 & 32 & $\mathrm{G}, \mathrm{Q}, \mathrm{T}, \mathrm{L}$ & $1.54 \pm 0.20$ & $0.26 \pm 0.05$ & $16.8 \pm 3.1$ \\
\hline & K7 & 7.0 & 242 & 37 & $\mathrm{G}, \mathrm{W}, \mathrm{L}$ & $1.93 \pm 0.20$ & $0.18 \pm 0.04$ & $9.20 \pm 2.2$ \\
\hline & K8 & 7.1 & 146 & 18 & $\mathrm{G}, \mathrm{W}, \mathrm{L}$ & $1.66 \pm 0.54$ & $0.13 \pm 0.02$ & $7.70 \pm 1.0$ \\
\hline & K10 & 7.0 & 140 & 25 & $\mathrm{G}, \mathrm{Q}, \mathrm{W}, \mathrm{An}$ & $0.39 \pm 0.04$ & $0.13 \pm 0.03$ & $33.3 \pm 6.7$ \\
\hline & \multicolumn{8}{|c|}{ Mining sediment } \\
\hline & $\mathrm{K}-\mathrm{C} 3 \mathrm{~A}$ & 7.3 & 221 & 4 & $\mathrm{G}, \mathrm{Q}, \mathrm{W}, \mathrm{L}, \mathrm{O}$ & $2.30 \pm 0.33$ & $1.19 \pm 0.08$ & $51.5 \pm 3.6$ \\
\hline & $\mathrm{K}-\mathrm{C} 3 \mathrm{~B}$ & 7.4 & 204 & 48 & $\mathrm{G}, \mathrm{Q}, \mathrm{W}, \mathrm{L}, \mathrm{O}$ & $1.91 \pm 0.19$ & $0.95 \pm 0.09$ & $49.9 \pm 4.6$ \\
\hline & $\mathrm{K}-\mathrm{T}$ & 7.3 & 172 & 34 & $\mathrm{G}, \mathrm{Q}, \mathrm{W}, \mathrm{L}, \mathrm{O}$ & $4.29 \pm 0.51$ & $0.28 \pm 0.04$ & $6.50 \pm 1.0$ \\
\hline & \multicolumn{8}{|l|}{ River sand } \\
\hline & $\mathrm{K}-\mathrm{C} 1$ & 6.8 & 198 & 154 & $\mathrm{G}, \mathrm{H}, \mathrm{Q}, \mathrm{W}, \mathrm{L}$ & $2.42 \pm 0.12$ & $0.33 \pm 0.01$ & $13.7 \pm 0.4$ \\
\hline & $\mathrm{K}-\mathrm{C} 2$ & 7.2 & 213 & 907 & $\mathrm{G}, \mathrm{H}, \mathrm{Q}, \mathrm{W}, \mathrm{L}$ & $3.69 \pm 0.24$ & $0.19 \pm 0.02$ & $5.00 \pm 0.6$ \\
\hline & K-FA1 & 7.7 & 38 & 941 & $\mathrm{G}, \mathrm{Q}, \mathrm{L}$ & $1.81 \pm 0.14$ & $0.16 \pm 0.03$ & $8.70 \pm 1.6$ \\
\hline \multirow[t]{17}{*}{ Poro } & \multicolumn{8}{|c|}{ Mining technosoil } \\
\hline & $\mathrm{P} 1$ & 7.0 & 141 & 28 & $\mathrm{G}, \mathrm{H}, \mathrm{T}, \mathrm{An}$ & $2.80 \pm 0.24$ & $0.08 \pm 0.02$ & $2.90 \pm 0.8$ \\
\hline & $\mathrm{P} 2$ & 6.7 & 145 & 17 & $\mathrm{G}, \mathrm{H}, \mathrm{Q}, \mathrm{L}$ & $3.69 \pm 0.99$ & $0.24 \pm 0.03$ & $6.50 \pm 1.0$ \\
\hline & P3 & 7.0 & 150 & 25 & $\mathrm{G}, \mathrm{H}, \mathrm{W}, \mathrm{L}, \mathrm{An}$ & $0.95 \pm 0.10$ & $0.14 \pm 0.02$ & $14.4 \pm 2.2$ \\
\hline & $\mathrm{P} 4$ & 7.0 & 147 & 23 & G & $0.53 \pm 0.10$ & $<0.01$ & - \\
\hline & P5 & 6.9 & 162 & 17 & $\mathrm{G}, \mathrm{H}, \mathrm{A}, \mathrm{W}, \mathrm{An}$ & $0.93 \pm 0.10$ & $<0.01$ & - \\
\hline & P6 & 7.2 & 148 & 37 & $\mathrm{G}, \mathrm{L}, \mathrm{An}, \mathrm{Al}$ & $0.23 \pm 0.10$ & $0.11 \pm 0.01$ & $47.8 \pm 5.2$ \\
\hline & $\mathrm{P} 7$ & 7.0 & 137 & 23 & $\mathrm{G}, \mathrm{H}, \mathrm{A}, \mathrm{W}, \mathrm{An}$ & $0.60 \pm 0.15$ & $0.20 \pm 0.02$ & $33.3 \pm 3.7$ \\
\hline & P8 & 7.2 & 141 & 36 & $\mathrm{G}, \mathrm{H}, \mathrm{W}, \mathrm{L}$ & $1.46 \pm 0.24$ & $0.07 \pm 0.02$ & $4.60 \pm 1.2$ \\
\hline & P9 & 7.1 & 150 & 25 & $\begin{array}{c}\mathrm{G}, \mathrm{H}, \mathrm{Q}, \mathrm{A}, \mathrm{W} \\
\mathrm{An}\end{array}$ & $1.48 \pm 0.18$ & $0.17 \pm 0.02$ & $11.4 \pm 1.6$ \\
\hline & $\mathrm{P} 10$ & 7.0 & 145 & 35 & G, H, Q, W, L & $0.59 \pm 0.14$ & $<0.01$ & - \\
\hline & \multicolumn{8}{|c|}{ Mining sediment } \\
\hline & P-E & 7.4 & 145 & 52 & $\mathrm{G}, \mathrm{Q}, \mathrm{T}, \mathrm{L}$ & $4.67 \pm 0.37$ & $0.09 \pm 0.01$ & $1.90 \pm 0.3$ \\
\hline & P-G & 7.1 & 189 & 155 & $\mathrm{G}, \mathrm{H}, \mathrm{Q}, \mathrm{W}, \mathrm{L}$ & $1.00 \pm 0.08$ & $<0.01$ & - \\
\hline & $\mathrm{P}-\mathrm{H}$ & 7.3 & 126 & 13 & $\mathrm{G}, \mathrm{Q}, \mathrm{T}$ & $0.29 \pm 0.03$ & $<0.01$ & - \\
\hline & \multicolumn{8}{|c|}{ Beach sand } \\
\hline & P-F & 7.6 & 195 & 401 & $\mathrm{G}, \mathrm{H}, \mathrm{A}$ & $0.90 \pm 0.14$ & $0.61 \pm 0.05$ & $67.3 \pm 6.0$ \\
\hline \multirow[t]{6}{*}{ MKM } & \multicolumn{8}{|c|}{ Mining sediment } \\
\hline & M-3B & 7.0 & 149 & 12 & $\mathrm{G}, \mathrm{M}, \mathrm{W}, \mathrm{O}$ & $2.02 \pm 0.19$ & $0.46 \pm 0.03$ & $22.5 \pm 1.4$ \\
\hline & $\mathrm{M}-3 \mathrm{C}$ & 7.1 & 147 & 27 & $\mathrm{G}, \mathrm{M}, \mathrm{W}, \mathrm{O}$ & $1.37 \pm 0.18$ & $0.69 \pm 0.06$ & $50.4 \pm 4.2$ \\
\hline & \multicolumn{8}{|l|}{ River sand } \\
\hline & M-2 & 6.7 & 247 & 8 & $\mathrm{~W}, \mathrm{C}, \mathrm{H}, \mathrm{G}$ & $3.81 \pm 0.32$ & $0.10 \pm 0.01$ & $2.52 \pm 0.3$ \\
\hline & M-3A & 7.3 & 136 & 238 & $\mathrm{G}, \mathrm{H}, \mathrm{W}, \mathrm{C}, \mathrm{An}$ & $1.33 \pm 0.11$ & $0.56 \pm 0.07$ & $43.5 \pm 5.5$ \\
\hline
\end{tabular}

The main mineral phases are $G$ Goethite, $H$ Hematite, $Q$ Quartz, $A$ Asbolane, $L$ Lizardite, $T$ Talc, $W$ Willemseite, An Antigorite, $O$ Orthochrysotile, $A l$ Albite, $C$ Chromite, $M$ Magnetite. n.a for not analyzed 
position sensitive detector, $\mathrm{K} \alpha \mathrm{Co}$ ). All samples contain iron oxides-hydroxydes and mainly goethite but also others expected mineral phases in ultramafic rocks alterites (Table 1). No As minerals occurring in nature were detected, and As is probably associated with iron oxides-hydroxides secondary phases (Seddique et al. 2008).

\section{As content in alterites}

For total As, $0.5 \mathrm{~g}$ was digested with aqua regia $(\mathrm{HCl} 5 \mathrm{~mL}$; $\mathrm{HNO}_{3} 1 \mathrm{~mL}$ ) in a microwave digester (Perkin Elmer-Multiwave 3000). The volume was then adjusted to $25 \mathrm{~mL}$. For exchangeable As, $1 \mathrm{~g}$ was extracted with $\mathrm{KH}_{2} \mathrm{PO}_{4}(25 \mathrm{~mL}$, $0.2 \mathrm{M}$ ) for $2 \mathrm{~h}$ before $10 \mathrm{~min}$ centrifugation at $4200 \mathrm{rpm}$. All reagents are of analytical grade and Milli-Q water from Millipore was used.

\section{$\operatorname{As}(\mathrm{III})$ or $\mathrm{As}(\mathrm{V})$ adsorption tests on alterites}

Adsorption experiments were performed on few samples previously washed $\left(4 \mathrm{~h}\right.$ in $\left.\mathrm{KH}_{2} \mathrm{PO}_{4} 0.4 \mathrm{M}\right)$ in order to remove naturally adsorbed As. Then, $1 \mathrm{~g}$ of washed sample was introduced into $25 \mathrm{~mL}$ of $\mathrm{As}(\mathrm{III})$ or $\mathrm{As}(\mathrm{V})$ solutions prepared with $\mathrm{As}_{2} \mathrm{O}_{3}$ and $\mathrm{H}_{3} \mathrm{AsO}_{4}\left(6-50 \mu \mathrm{g} \mathrm{L}^{-1}\right)$. The solution was agitated for $48 \mathrm{~h}$ at $\mathrm{pH}$ ranging 6.5-7.3 before As(III) or $\mathrm{As}(\mathrm{V})$ analysis remaining in the supernatant. As adsorbed (\%) was calculated with As concentration in the solution at initial time $\left(C_{0}, \mu \mathrm{g} \mathrm{L}^{-1}\right)$ and at time $t\left(C_{t}, \mu \mathrm{g} \mathrm{L}^{-1}\right)$ (Eq. 1):

As adsorbed $(\%)=\frac{C_{0}-C_{t}}{C_{0}} \times 100$

The distribution coefficient, $K_{d}\left(\mathrm{~L} \mathrm{~kg}^{-1}\right)$ was calculated using Eq. (2):

$K_{d}=\frac{\text { As adsorbed at equilibrium }\left(\mathrm{mg} \mathrm{kg}^{-1}\right)}{\text { Initial As concentration in solution }\left(\mathrm{mg} \mathrm{L}^{-1}\right)}$

\section{As analysis}

All solutions were filtrated through $0.45 \mu \mathrm{m}$ acetate filters before analysis. Three references materials (soils Wepal ISE 884,885 and 961) were used for aqua regia digestion $(n=1$ for ISE $884, n=12$ for ISE 885 and $n=3$ for ISE 96) and analytical measurements ( 3 analytical replicates) validation (supplementary material SM1).

Aqua regia digested samples were analyzed by ICPOES (Varian -730-ES at wavelengths $198.980 \mathrm{~nm}$ and $197.198 \mathrm{~nm}$ ). In alterites, total As contents were below the ICP-OES quantification limit $\left(\mathrm{QL}=100 \mu \mathrm{g} \mathrm{L}^{-1}\right.$ or $5 \mathrm{mg} \mathrm{As} \mathrm{kg}{ }^{-1}$ ) and were then analyzed by voltammetry (Metrohm-884 Professional VA) with a gold microwire working electrode, scTRACE gold (Metrohm Application Bulletin 416). $2 \mathrm{~mL}$ of electrolyte (Sulfamic acid $1 \mathrm{M}$, Citric acid $0.5 \mathrm{M}, \mathrm{KCl} 0.45 \mathrm{M}$ ) was added to $10 \mathrm{~mL}$ of diluted sample solution. For As(III + V) measurement, the deposition potential is $-1 \mathrm{~V}$ for $90 \mathrm{~s}$, the sweep potential is -0.3 to $0.2 \mathrm{~V}$ with $0.01 \mathrm{~V}$ step and a sweep rate of $0.4 \mathrm{~V} \mathrm{~s}^{-1}$. As peak is detected around $81 \mathrm{mV}$ (supplementary material SM2). In order to reduce interferences (interfering peak at $-52 \mathrm{mV}$ ), samples were diluted 10 times and a cationic exchange resin was added (1 g DOWEX 50WX8 hydrogen form) for excess of metallic ions removal. Due to ICP-OES detection limits, exchangeable As was analyzed by voltammetry, for $\mathrm{As}(\mathrm{III}+\mathrm{V})$ and $\mathrm{As}(\mathrm{III})$. As(III) is measured with a deposition potential at $-0.5 \mathrm{~V}$ (other parameters being unchanged). $\mathrm{As}(\mathrm{V})$ content is the difference between the two voltammetric measurements. No purification step with chelex resin was required. As remaining in the supernatant after $\mathrm{As}(\mathrm{III})$ and $\mathrm{As}(\mathrm{V})$ adsorption experiments were also analyzed by voltammetry and As(III) possible oxydation or $\mathrm{As}(\mathrm{V})$ possible reduction through contact of alterites particles during the adsorption experiments was controlled.

\section{Results and discussion}

In order to see if ultramafic rocks alterites can be a significant source of As in surface waters by their total content and ability to absorb and release As, we studied the total and the exchangeable As content in all samples using aqua regia digestion and monopotassium phosphate leaching. Then, we also studied the adsorption capacity of some samples using batch experiments.

\section{Total As}

Total As content ranges $0.20-5.14 \mathrm{mg} \mathrm{kg}^{-1}$ (Table 1) (first quartile, median and third quartile values are, respectively, $0.9 ; 1.48$ and $2.42 \mathrm{mg} \mathrm{kg}^{-1}$ ). No significant difference is noted between the three mining sites for mean total As (Fig. 1) or between mining technosoils and mining sediments collected in the decanters or downstream mining sites. As contents are in agreement with those measured in ultramafic rocks like peridotite, dunite, kimberlite $\left(0.03-15.8 \mathrm{mg} \mathrm{kg}^{-1}\right)$ (Smedley and Kinniburgh 2002) but in serpentinite, contents can range 19-449 $\mathrm{mg} \mathrm{kg}^{-1}$ and it can reach $1104 \mathrm{mg} \mathrm{kg}^{-1}$ in mining contaminated lake sediments or $8000 \mathrm{mg} \mathrm{kg}^{-1}$ in soils near sulfide deposits (Ryan et al. 2011). As contents in New Caledonian alterites are then rather low in view of literature data and measurements could be made due to the high sensitivity of voltammetric analysis. No high over-concentration in alterites collected in or around mines are fortunately observed, and they do not seem to be highly enriched due to Ni-mining activities, but As is detected in all alterites 
and seems then to be systematically present. The systematic presence of arsenic was not expected and ultramafic rock's alterites, if massively dispersed as suspended particulate matter are therefore a significant source of particulate As in surface waters.

\section{Exchangeable As}

Exchangeable As represents the fraction that is adsorbed onto the particle surface and that can be mobile i.e., easily soluble. No exchangeable As(III) was detected and mean exchangeable $\mathrm{As}(\mathrm{V})$ is $0.25 \mathrm{mg} \mathrm{kg}^{-1}$ (first quartile, median and third quartile values are, respectively, 0.09; 0.157 and $0.268 \mathrm{mg} \mathrm{kg}^{-1}$ ). High values, above the third quartile are noted for samples K-C1, K-C3, K-T, P-F, M-3A, M3-B and M3-C $\left(0.33-1.19 \mathrm{mg} \mathrm{kg}^{-1}\right)$, all collected downstream the mines (Fig. 2). For these displaced materials, a light overconcentration onto alterites' surface is then not excluded, they could have possibly behave as As sink during their course. No relationship could be established between exchangeable As content and the size particle distribution and no significant difference is noticed between the three mining sites (Fig. 1). Anyway, the proportion of exchangeable $\mathrm{As}(\mathrm{V})$ with first quartile, median and third quartile values being, respectively, $4.2 ; 10.3$ and $33.5 \%$ of the total As indicates that if carried as suspended particulate matter, alterites can be a significant source of soluble $\mathrm{As}(\mathrm{V})$ to surface waters.

\section{As adsorption tests}

Adsorption reach saturation with 70 to $95 \%$ of initial $\mathrm{As}(\mathrm{III})$ or $\mathrm{As}(\mathrm{V})$ adsorbed, excepted for sample K-C1 adsorbing $100 \%$ of initial As(III) (Table 2). As(III) as well
Table 2 As(III) and As(V) adsorption capacity of three samples $(1 \mathrm{~g} / 25 \mathrm{~mL})$-not calculated because saturation not obtained

\begin{tabular}{llllll}
\hline Sample & $\begin{array}{l}\text { Initial As } \\
\text { in solution } \\
\left(\mu \mathrm{g} \mathrm{L}^{-1}\right)\end{array}$ & \multicolumn{2}{l}{ As adsorbed } & \multicolumn{2}{l}{$K_{d}$} \\
\cline { 3 - 5 } & & $(\%)$ & $\left(\mathrm{mg} \mathrm{kg}^{-1}\right)$ & $\left(\mathrm{mg} \mathrm{m}^{-2}\right)$ & $\left(\mathrm{L} \mathrm{kg}^{-1}\right)$ \\
\hline K-C1 & $\mathrm{As}(\mathrm{III}) 5$ & 100 & 0.2495 & 0.0012 & - \\
River sand & $\mathrm{As}(\mathrm{III}) 13$ & 100 & 0.6381 & 0.0030 & - \\
& $\mathrm{As}(\mathrm{V}) 8$ & 83 & 0.4108 & 0.0020 & 51.4 \\
& $\mathrm{As}(\mathrm{V}) 18$ & 79 & 0.9240 & 0.0044 & 51.3 \\
K-C3A & $\mathrm{As}(\mathrm{III}) 31$ & 92 & 0.7128 & 0.0013 & 23.0 \\
Mining sedi- & $\mathrm{As}(\mathrm{III}) 50$ & 85 & 1.0487 & 0.0019 & 21.0 \\
ment & $\mathrm{As}(\mathrm{V}) 17$ & 72 & 0.3054 & 0.0005 & 18.0 \\
& $\mathrm{As}(\mathrm{V}) 46$ & 70 & 0.8070 & 0.0014 & 17.5 \\
K-C3B & $\mathrm{As}(\mathrm{III}) 44$ & 95 & 1.0469 & 0.0004 & 23.8 \\
Mining sedi- & $\mathrm{As}(\mathrm{V}) 31$ & 88 & 0.6758 & 0.0003 & 21.8 \\
ment & & & & & \\
\hline
\end{tabular}

Ultramafic rock's alterites rich in goethite are effective in adsorbing arsenite and arsenate

as $\mathrm{As}(\mathrm{V})$ are highly adsorbed and no significant conversion occurred in solution (which does not exclude conversion at the surface of alterites). As(III) and $\mathrm{As}(\mathrm{V})$ adsorption onto alterites, ranging $0.0003-0.0044 \mathrm{mg} \mathrm{m}^{-2}$, is in agreement with $0.00061,0.0041$ and $0.055 \mathrm{mg} \mathrm{As}(\mathrm{V}) \mathrm{m}^{-2}$ obtained with laterite, goethite and hematite, respectively (Aredes et al. 2012). As(III) and As(V) partition coefficient for alterites ranges $17.5-51.4 \mathrm{~L} \mathrm{~kg}^{-1}$ in accordance with $25-200 \mathrm{~L} \mathrm{~kg}^{-1}$ for, respectively, natural hematite and goethite (Bowell 1994). These adsorption tests revealed that their maximum adsorption capacity for arsenate and arsenite are $1.05 \mathrm{mg} \mathrm{kg}^{-1}$. Ultramafic rock's alterites rich in goethite are effective in adsorbing arsenite and arsenate confirming that they may be source or sink of As for surface waters.
Fig. 2 Exchangeable arsenate detected in ultramafic rocks' alterites collected in or downstream mining sites. Samples with high exchangeable values, greater than the third quartile $Q_{3}$ $0.280 \mathrm{mg} \mathrm{kg}^{-1}$ are all collected downstream the mining sites

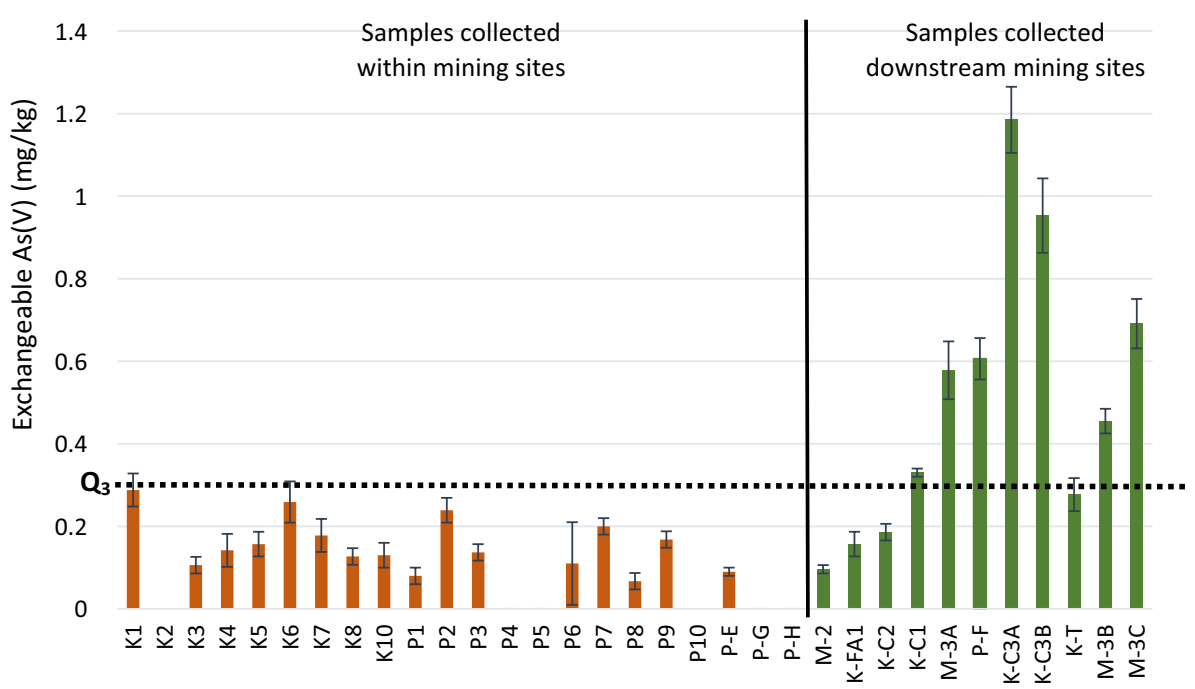




\section{Conclusion}

Arsenic is present in all the samples with total contents ranging $0.20-5.14 \mathrm{mg} \mathrm{kg}^{-1}$. The present work demonstrates that ultramafic rock's alterites contain arsenic even though the primary mineralogical source of As is unknown. They can be a source of particulate As if transported as suspended particulate matter. No exchangeable arsenite was detected, but the median value for exchangeable arsenate is $0.16 \mathrm{mg} \mathrm{kg}^{-1}$ representing $10.3 \%$ of the total As content. Ultramafic materials contain, then, a significant proportion of arsenate that can be dissolved to surface waters. Adsorption experiments revealed that the maximum adsorption capacity of mining sediments for arsenate and arsenite was $1.05 \mathrm{mg} \mathrm{kg}^{-1}$. Displaced materials can then be a source or sink of As. Mining companies are encouraged to prevent the transport of solid particles by runoff to downstream watersheds. For tropical islands with ultramafic catchments providing water resource for the population, these results underline that As should be systematically measured for water quality survey and that As behavior and distribution in ultramafic catchments affected or not by mining activities should be studied in more details.

Acknowledgements This work was funded by the "Centre National de Recherche et Technologie" Nickel and its environment and was part of the project "DYNAMINE". The authors thank Camille Pasquet and Aurélie Boula for some samples providing.

\section{References}

Aredes S, Klein B, Pawlik M (2012) The removal of arsenic from water using iron oxide minerals. J Clean Prod 60:71-76. https://doi. org/10.1016/j.jclepro.2012.10.035

Basu A, Saha D, Saha R et al (2014) A review on sources, toxicity and remediation technologies for removing arsenic from drinking water. Res Chem Intermed 40:447-485. https://doi.org/10.1007/ s11164-012-1000-4

Becquer T, Petard J, Duwig C et al (2001) Mineral, chemical and charge properties of Geric Ferralsols from New Caledonia. Geoderma 103(3):291-306. https://doi.org/10.1016/S0016-7061(01)00045-3

Bossy A, Grosbois C, Hendershot W et al (2012) Contributions of natural arsenic sources to surface waters on a high grade arsenicgeochemical anomaly (French Massif Central). Sci Total Environ 432:257-268. https://doi.org/10.1016/j.scitotenv.2012.05.090

Bowell RJ (1994) Sorption of arsenic by iron oxide and oxyhydroxides in soils. Appl Geochem 9(3):279-286. https://doi. org/10.1016/0883-2927(94)90038-8
Gunkel-Grillon P, Laporte-Magoni C, Le Mestre M, Bazire N (2014) Toxic chromium release from nickel mining sediments in surface waters, New Caledonia. Environ Chem Lett 12:511-516. https:// doi.org/10.1007/s10311-014-0475-1

Juillot F et al (2019) Rapport scientifique final. Programme DYNAMINE «Dynamique des métaux de la mine au lagon». CNRT «Nickel and son environnement» (CSF 9PS2013-CNRT. IRD/DYNAMINE)

Merola RB, Hien TT, Quyen DTT, Vengosh A (2015) Arsenic exposure to drinking wtare in the Mekong Delta. Sci Total Environ 511:544-552. https://doi.org/10.1016/j.scitotenv.2014.12.091

Nguyen TH, Tran HN et al (2020) Laterite as a low-cost adsorbent in a sustainable decentralized filtration system to remove arsenic from groundwater in Vietnam. Sci Total Environ 699:134267. https:// doi.org/10.1016/j.scitotenv.2019.134267

Pettine M, Camusso M, Martinotti W (1992) Dissolved and particulate transport of arsenic and chromium in the Po River. Sci Total Environ 119:253-280. https://doi.org/10.1016/0048-9697(92)90268-W

Prohaska T, Stingeder G (2005) Speciation of arsenic. In: Cornelis R (ed) Handbook of elemental speciation II-species in the environment, food, medecine and occupational health. Wiley, Chichester, pp 69-85. https://doi.org/10.1002/0470856009

Ryan PC, Kim J, Wall AJ et al (2011) Ultramafic-derived arsenic in a fractured bedrock aquifer. Appl Geochem 26:444-457. https://doi. org/10.1016/j.apgeochem.2011.01.004

Sattar A, Xie S, Hafeez MA et al (2016) Metabolism and toxicity of arsenicals in mammals. Environ Toxicol Pharmacol 48:214-224. https://doi.org/10.1016/j.etap.2016.10.020

Seddique AA, Masuda H, Mitamura M et al (2008) Arsenic release from biotite into a Holocene groundwater aquifer in Bangladesh. Appl Geochem 23(8):2236-2248. https://doi.org/10.1016/j.apgeo chem.2008.03.007

Siddiqui SI, Chaudhry SA (2017) Iron oxide and its modified forms as an adsorbent for arsenic removal: a comprehensive recent advancement. Process Saf Environ Prot 111:592-626. https://doi. org/10.1016/j.psep.2017.08.009

Smedley PL, Kinniburgh DG (2002) A review of the source, behaviour and distribution of arsenic in natural waters. Appl Geochem 17(5):517-568. https://doi.org/10.1016/S0883-2927(02)00018-5

States JC, Srivastava S, Chen Y, Barchowsky A (2009) Arsenic and cardiovascular disease. Toxicol Sci 107(2):312-323. https://doi. org/10.1093/toxsci/kfn236

Zhang C, Kibriya MG, Jasmine F et al (2018) A study of telomere length, arsenic exposure, and arsenic toxicity in a Bangladeshi cohort. Environ Res 164:346-355. https://doi.org/10.1016/j.envre s.2018.03.005

Publisher's Note Springer Nature remains neutral with regard to jurisdictional claims in published maps and institutional affiliations. 